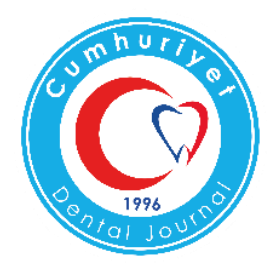

\title{
EFFECT OF TWO ACTIVATED BLEACHING TECHNIQUES \\ ON SURFACE ROUGHNESS OF DIFFERENT ESTHETIC RESTORATIVE MATERIALS
}

\author{
İki Aktive Olan Beyazlatma Tekniğinin Farklı Estetik Restoratif \\ Materyallerin Yüzey Pürüzlülüğ̈̈ Üzerine Etkisi
}

Tuncay ALPTEKIN ${ }^{1}$, Özgün Yusuf ÖZYILMAZ ${ }^{2}$, Filiz AYKENT ${ }^{3}$, Haluk Barış KARA ${ }^{2}$

\section{Makale Kodu/Article Code : 192786 \\ Makale Gönderilme Tarihi $\quad$ : 16.06 .2016 \\ Kabul Tarihi} \begin{abstract}
Objectives: The aim of this in vitro study was to evaluate surface roughness of six different restorative materials during office bleaching procedures with blue light emitted diode (LED) and diode laser photo activation.
\end{abstract}

Materials and Methods: Filtek TM supreme, Tetric Evo Ceram, Tescera ATL, Clearfill Majesty Esthetic, Durafill VS and IPS Empress 2 materials were evaluated in this study. Twenty specimens, $10 \mathrm{~mm}$ in diameter and $2 \mathrm{~mm}$ thick, were fabricated from each material using a teflon mold. All specimens were randomly assigned to two groups $(n=10)$. Group 1 received two topical applications of $35 \%$ hydrogen peroxide for $20 \mathrm{~s}$. And was photoactivated using LED. Group 2 received topical application of $46 \%$ hydrogen peroxide using diode laser. Surface roughness values were measured prior to and following bleaching procedures by using a profilometer. Data were analyzed statistically, by one-way-analysis of variance (ANOVA), post-hoc Tamhane's $\mathrm{T} 2$ and independent $\mathrm{t}$ tests.

Results: Surface roughness values for all restorative materials tested increased after both bleaching procedures $(\mathrm{p}<0.05)$. Tescera ATL bleached with diode laser photo activation showed higher surface roughness value than LED activation $(\mathrm{p}<0.05)$. However, there were no significant differences in two bleaching methods for other restorative materials $(\mathrm{p}>0.05)$.

Conclusions: Although clinical effects depend on in-vivo conditions, the effects of office bleaching agents should be known and applied cautiously when a colored restoration is bleached or a restoration is neighboured with the tooth bleached.

Keywords: Esthetic restorative materials, Dental porcelain, Teeth bleaching, Surface roughness, Semiconductor lasers

\section{ÖZ}

Amaçlar: $\mathrm{Bu}$ in vitro çalışmanın amacı, mavi ışık yayan diyot (LED) ve diyot lazer ile foto aktive olan ofis tipi beyazlatma prosedürleri esnasında altı farklı restoratif materyalin yüzey pürüzlülüğünü değerlendirmektir.

Materyal ve Metotlar: Bu çalışmada Filtek TM supreme, Tetric Evo Ceram, Tescera ATL, Clearfill Majesty Esthetic, Durafill VS ve IPS Empress 2 materyalleri kullanıldı. Yirmi örnek; her biri $10 \mathrm{~mm}$ çapında $2 \mathrm{~mm}$ kalınlığında olacak şekilde teflon kalıp kullanılarak oluşturuldu. Bütün örnekler rastgele iki gruba ayrıldı $(\mathrm{n}=10)$. Grup 1' de topikal uygulanan \%35'lik hidrojen peroksit LED kullanılarak 20 saniye süreyle foto aktive edildi. Grup 2' de \%46'llk hidrojen peroksit diode lazer kullanılarak topikal olarak uygulandı. Yüzey pürüzlülüğü değerleri başlangıç ve beyazlatma işlemleri sonrasında olmak üzere profilometre yardımıyla ölçüldü. Veriler tek-yönlü varyans analizi (ANOVA), Tamhane's T2 ve bağımsız t testleri yapılarak istatiksel olarak analiz edildi.

Sonuçlar: Yüzey pürüzlülüğü değerleri test edilen tüm restoratif materyallerde her iki beyazlatma prosedüründe de artmıştır $(\mathrm{p}<0,05)$. Diode lazer foto aktivasyonu ile beyazlatılan Tescera ATL, LED ile aktive edilenden daha yüksek yüzey pürüzlülüğü değeri gösterdi $(p<0,05)$. Fakat diğer restoratif materyaller için iki beyazlatma prosedüründe de önemli farklılıklar ortaya çıkmadı $(\mathrm{p}>0,05)$.

Çıkarımlar: Klinik etkiler in-vivo şartlara bağlı olmasına rağmen ofis tipi beyazlatma ajanlarının etkileri bilinmeli ve renklenmiş bir restorasyon beyazlatıldığında veya beyazlatılmış diş ile komşu restorasyon varlığında dikkatle kullanılmalıdır.

Anahtar kelimeler: Estetik restoratif materyaller, Dental porselen, Diş beyazlatma, Yüzey pürüzlülüğü, Yarı iletken lazerler

\footnotetext{
${ }^{1}$ Department of Conservative Dentistry, The Ministry of Health of Turkey, Balgat Dentaland Oral Health Center, Ankara, Turkey

${ }^{2}$ Department of Prosthodontics, Faculty of Dentistry, Istanbul Medipol University, Istanbul, Turkey

${ }^{3}$ Department of Prosthodontics, Faculty of Dentistry, Yildirim Beyazit University, Ankara, Turkey
} 


\section{INTRODUCTION}

Dental bleaching is the best conservative treatment to whitening the natural teeth in order to improve aesthetic reasons. ${ }^{1,2}$ There are two techniques for bleaching vital teeth: in-office under supervision of a dentist, or at-home, with the use of lower concentration of whitening agents in special trays. In-office bleaching systems produced more rapid results, professional controls the contact of whitening agents with soft tissues and avoidance of the material ingestion. On the other hand, at-home bleaching is being a lower cost procedure in comparison with in-office treatment, being easy to use by patients. Nevertheless, common problems for this technique are sensitivity of the tooth and soft tissue, incorrect use of by patients and overexposure to the over-the-counter products without professional control. ${ }^{3-7}$

Hydrogen peroxide, sodium perborate and carbamide peroxide are the agents used for dental bleaching procedures. ${ }^{6-8}$ To enhance or accelerate the whitening process, heat activation of bleaching agent by light, heat or laser is described in the literature. ${ }^{9}$ Lightactivated bleaching is a method of tooth whitening that can be achieved by utilizing highly concentrated bleaching gel (35 to 50\% hydrogen peroxide). Halogen light, derived from relatively low-cost technology, produces high heat generation and loss of pulpal vitality. LEDs (light emitting diodes) are also able to produce light in a specific wavelength and have low amounts of wasted energy and minimum heat generation. $^{10,} 11$ Laser technology has rapidly developed during last two decades. Its applications have been successfully implemented in the medical professions. ${ }^{12}$ Laser tooth bleaching officially started 1996, with the approval of the argon laser $(480 \mathrm{~nm})$ and the $\mathrm{CO}_{2}$ laser $(10.6 \mu \mathrm{m}) .{ }^{13,14}$ Today three types lasers; $\operatorname{argon}(488 / 514 \mathrm{~nm}), \mathrm{CO}_{2}(10.6 \mu \mathrm{m})$, and diode $(790-980 \mathrm{~nm})$ lasers are approved for tooth whitening according to US Food and Drug Administration. ${ }^{10}$
In literature several reports exist regarding the influence of bleaching agents on surface morphology of composite - $^{15-20}$ and ceramic materials ${ }^{15}, 21,22$ and these studies present controversial findings. Beside this there is no information published regarding the potential effects of activated bleaching techniques on the surface roughness of the composites, ceramic and ormocer. Therefore, the purpose of this study was to evaluate the effect of two in-office bleaching techniques (blue light-emitted diode (LED) activated 35\% HP and diode laser activated $46 \% \mathrm{HP}$ ) on the surface roughness of composite materials, ormocer and ceramic. Two null hypothesis were purposed: 1) that the surface roughness of restorative materials would not affected by bleaching techniques. 2) that there was no significant difference between two bleaching techniques.

\section{MATERIALS AND METHODS}

The effect of two commercial in-office bleaching techniques on the surface roughness of 6 restorative materials was evaluated. The materials, product names, and manufacturers are listed in Table 1.

Table 1. Materials used

\begin{tabular}{|l|c|l|c|c|}
\hline \multicolumn{1}{|c|}{ Materials } & Abbreviation & \multicolumn{1}{c|}{ Manufacturer } & Type & Lot Numbers \\
\hline Filtek ${ }^{\mathrm{TM}}$ Supreme XT & FS & $\begin{array}{l}\text { 3M ESPE Seefeld, } \\
\text { Germany }\end{array}$ & Nanofilled & 20090220 \\
\hline $\begin{array}{l}\text { Clearfill MajestyTM } \\
\text { Esthetic }\end{array}$ & CME & $\begin{array}{l}\text { Kuraray Medical } \\
\text { Inc, Okayama, Japan }\end{array}$ & Nanofilled & $0029 \mathrm{AB}$ \\
\hline Tetric $囚$ EvoCeram & TEC & $\begin{array}{l}\text { Ivoclar Vivadent } \\
\text { AG, Schaan, } \\
\text { Liechtenstein }\end{array}$ & Nanohybrid & K29326 \\
\hline Durafill $囚$ VS & Df & $\begin{array}{l}\text { Heraeus Kulzer } \\
\text { GmbH, Hanau, } \\
\text { Germany }\end{array}$ & Microfilled & 010214 \\
\hline Tescera ${ }^{\mathrm{TM}}$ ATL & TATL & $\begin{array}{l}\text { Bisco Inc. } \\
\text { schaumburg, U.S.A }\end{array}$ & Ormocer & 0700004069 \\
\hline IPS Empress 2® & IPS2 & $\begin{array}{l}\text { Ivoclar Vivadent } \\
\text { AG, Schaan, } \\
\text { Liechtenstein }\end{array}$ & Ceramic & M22932 \\
\hline \hline
\end{tabular}

Twenty discs were fabricated by using Teflon molds (10-mm diameter, $2 \mathrm{~mm}$ thickness) from each of the restorative materials. Teflon molds were positioned on a transparent plastic matrix strip (Universal strips; Extra Dental, Istanbul, Turkey) lying on a glass plate and then filled with the restorative composite materials. After having inserted the materials into the teflon mold, a transparent plastic matrix strip was put over them and a 
glass slide was placed in order to flatten the surface. A glass slide was then placed over and pressure was applied to extrude excess materials. Filtek ${ }^{\mathrm{TM}}$ Supreme (FS), Clearfil Majesty ${ }^{\mathrm{TM}}$ Esthetic (CME), Tetric ${ }^{\mathbb{B}}$ EvoCeram (TEC) and Durafill (Df) composite materials were then light polymerized for $40 \mathrm{~s}$ in two steps through the glass slide with a blue lightemitted diode (Bluephase Ivoclar Vivadent Schaan, Liechtenstein) with irradiance of 470 $\mathrm{mW} / \mathrm{cm}^{2}$, constantly monitored by a radiometer (Curing Radiometer Model 100, Demetron Corp., Danbury, CT, USA). A total of 80 composite specimens were made for this study. Tescera ATL (TATL) specimens were polymerized using the same light unit for $180 \mathrm{~s}$ in accordance with the manufacturer's directions. As for the polymerization unit (BISCO, Inc, Schaumburg, IL, USA) provided for TATL specimens, it comprised two specialized cups (one for pressure/light and one for water/pressure/light/heat). TATL specimens were placed in one increment and polymerized with light polymerization cup for 5 minutes. The specimens were then removed from first cup and ormocer specimens were postcured in the heat cup submerged in water at a temperature of $120^{\circ} \mathrm{C}$ andunder a pressure of 6 bar for 13 minutes. A total of 20 ceromer specimens were made. Composite and ormocer specimens were regularized with a sequence of $600-, \quad 1,000-$, 1,200-grit aluminum oxide abrasive papers under running water using the Metaserve2000 polishing machine (Buehler UK Ltd. Coventry, West Midlands, England) with hand pressure to obtain a well-planeshaped surface that allowed positioning of specimens for the roughness measurements. And then specimens were polished with a felt disc by same machine and a single investigator.

A leucite based all-ceramic (IPS Empress2, IPS2) specimens $(10 \mathrm{~mm}$ diameter and $2 \mathrm{~mm}$ thickness) were waxed(S-U-Ceramo-CarvingWax, Schuler-Dental, Ulm, Germany) with using a metal mold. The wax specimens were sprued, and then pressed after investment. All procedures were performed with IPS2 materials following the manufacturer's recommendations. Ceramic specimens were then polished with 220-, 400-, 600-, 1000-grit aluminum oxide abrasive papers under water and glazed according to the manufacturer's instructions. A total of 20 ceramic specimens were made.

Finished specimens were cleaned in distilled water with an ultrasonic cleaner (Biosonic UC 50, ColteneWhaledent, Cuyahoga Falls, OH, USA) for 5 minutes. Then, they were dried and stored in distilled water at room temperature for 24 hours before the test procedure.

A total of 120 specimens, 20 of each of the composite materials, ormocer and ceramic were fabricated and randomly divided into two groups $(\mathrm{n}=10)$ according to bleaching procedure. The first group specimens were bleached with Whiteness HP (WHP) (Dentscare LTDA, Joinville, Brazil) which is contain $35 \%$ hydrogen peroxide (HP), as the bleaching agent. The red activator was mixed the colorless bleaching gel at the moment of use according to the manufacturer's instructions. The mixture was applied on the surface of specimens with approximately $1 \mathrm{~mm}$ thick layer for 10 minutes and specimens were photoactivated with LED for $20 \mathrm{~s}$. Following this, the bleaching agents were washed off. This procedure was repeated 4 times with a 2-min interval between them.

The second experimental group specimens were bleached with Laserwhite 20 (LW) (MT Promedt GmbH St. Ingbert, Germany) which is contain $46 \%$ HP. The caps were removed from both the activator and base gel syringes. The two syringes were connected by twisting one syringe onto other until fully tightened. To mix, pushed one syringe into other and reversed action for 25 times and it was applied approximately $1 \mathrm{~mm}$ thick layer on the specimen's surface for 5 minutes and then photoactivated witha diode laser (EzlaseTM Laser, wavelength $980 \mathrm{~nm}$, average power 7 watt, energy setting $200 \mathrm{~J}$, continuous mode) for $30 \mathrm{~s}$. The bleaching agents remained on the 
specimens surfaces for another 5 minutes and irradiated again for $30 \mathrm{~s}$. Following this, the bleaching agents were washed off. This procedure was repeated 2 times with a 5-min interval between them. After all application surfaces were washed with distilled water and dried with oil-free compressed air.

The average surface roughness $(\mathrm{Ra}, \mu \mathrm{m})$ of the treated specimens were measured with the MitutoyoSurftest-402 Surface Roughness Tester (Surftest 402 Analyzer Mitutoyo Corporation, Tokyo, Japan). Three traces were recorded for each specimen at three different locations (parallel, perpendicular, and oblique). The mean surface roughness value was calculated by averaged of the three measurements. All readings were performed by a single investigator. Roughness values were recorded at baseline and after exposure to the bleaching agents for each specimen. For surface characterization, one representative specimen from each group with Ra values close to the mean values were selected. The specimen was coated with gold and examined under a scanning electron microscope (SEM), (LEO 440, Electron Microscopy Ltd, Cambridge, USA).

\section{Data Analysis:}

Statistical analyses were performed with SPSS 15.0 (Windows; SPSS Inc, Chicago, IL, USA) for WINDOWS. Sapiro-Wilk test was used for the measurement of normalization of data and parametrical tests were used for statistical analysis. The baseline measurements of roughness of the materials were accepted covariant values and Univariant analysis was used to evaluate differences between materials and study groups. If there were significantly differences between 6 different materials, then data were analyzed by using one-way ANOVA test. The homogeneity of variances was measured by using Levene's test. Because the values of the roughness were not homogen distribution, post hoc Tamhane's T2 test was used for the statistical analysis. If statistically significant differences were found between two bleaching procedures, independent t-test was used for the statistical analysis. $\mathrm{P}$ values less than 0.05 were considered to be statistically significant in all tests $(\mathrm{p}<0.05)$.

\section{RESULTS}

The mean values and standard deviations of roughness measurements of each study group are presented in Table 2, respectively. The percentage values of the discrepancies of roughness (Table 2) measurements were also recorded in WHP and LW groups.

Table 2. Surface roughness measurements of the study groups and materials before and after bleaching procedures (Mean $\pm \mathrm{SD}$ )

\begin{tabular}{|c|c|c|c|c|}
\hline Materials & $\begin{array}{c}\text { Bleaching } \\
\text { Procedures }\end{array}$ & $\begin{array}{c}\text { Before } \\
\text { Bleaching }\end{array}$ & After Bleaching & \begin{tabular}{|c|} 
Differences in \\
Percentage Values \\
of Surface \\
Roughness \\
\end{tabular} \\
\hline $\begin{array}{l}\begin{array}{l}\text { Filtek } \\
(\mathrm{n}=20)\end{array} \\
\text { TM Supreme (FS) }\end{array}$ & $\begin{array}{l}\text { WHP }(\mathrm{n}=10) \\
\text { LW }(\mathrm{n}=10)\end{array}$ & $\begin{array}{l}0.15 \pm 0.04 \\
0.17 \pm 0.08\end{array}$ & $\begin{array}{l}0.18 \pm 0.04^{\mathrm{a}} \\
0.21 \pm 0.08^{\mathrm{a}}\end{array}$ & $\begin{array}{l}31.37 \pm 40.01 \\
21.70 \pm 19.54\end{array}$ \\
\hline $\begin{array}{l}\text { Clearfil Majesty } \\
\text { Esthetic }(\mathrm{CME})(\mathrm{n}=20)\end{array}$ & $\begin{array}{l}\text { WHP }(\mathrm{n}=10) \\
\text { LW }(\mathrm{n}=10)\end{array}$ & $\begin{array}{l}0.21 \pm 0.11 \\
0.30 \pm 0.09\end{array}$ & $\begin{array}{l}0.28 \pm 0.12^{\mathrm{a}} \\
0.40 \pm 0.07^{\mathrm{a}}\end{array}$ & $\begin{array}{l}46.72 \pm 44.02 \\
39.72 \pm 34.94\end{array}$ \\
\hline $\begin{array}{l}\text { Tetrici" EvoCeram } \\
(\mathrm{TEC})(\mathrm{n}=20)\end{array}$ & $\begin{array}{l}\text { WHP( }(\mathrm{n}=10) \\
\text { LW }(\mathrm{n}=10)\end{array}$ & $\begin{array}{l}0.23 \pm 0.10 \\
0.21 \pm 0.10\end{array}$ & $\begin{array}{l}0.36 \pm 0.13^{\mathrm{a}} \\
0.37 \pm 0.12^{\mathrm{b}}\end{array}$ & $\begin{array}{c}59.03 \pm 28.62 \\
115.86 \pm 177.02\end{array}$ \\
\hline Durafill (Df) $(n=20)$ & $\begin{array}{l}\text { WHP }(\mathrm{n}=10) \\
\text { LW }(\mathrm{n}=10)\end{array}$ & $\begin{array}{l}0.19 \pm 0.07 \\
0.25 \pm 0.05\end{array}$ & $\begin{array}{c}0.38 \pm 0.08^{\mathrm{a}} \\
-13.89 \pm 12.41^{\mathrm{a}}\end{array}$ & $\begin{array}{l}35.46 \pm 26.38 \\
61.05 \pm 55.19\end{array}$ \\
\hline $\begin{array}{l}\text { Tescera ATL (TATL) } \\
(\mathrm{n}=20)\end{array}$ & $\begin{array}{l}\text { WHP }(\mathrm{n}=10) \\
\text { LW }(\mathrm{n}=10)\end{array}$ & $\begin{array}{l}0.15 \pm 0.02 \\
0.19 \pm 0.07\end{array}$ & $\begin{array}{l}0.18 \pm 0.05^{\mathrm{a}} \\
0.32 \pm 0.16^{\mathrm{a}}\end{array}$ & $\begin{array}{c}21.10 \pm 19.18^{\mathrm{Y}, *} \\
71.59 \pm 54.01\end{array}$ \\
\hline $\begin{array}{l}\text { IPS Empress } 2 \text { (IPS2) } \\
(\mathrm{n}=20)\end{array}$ & $\begin{array}{l}\text { WHP }(\mathrm{n}=10) \\
\text { LW }(\mathrm{n}=10)\end{array}$ & $\begin{array}{l}0.60 \pm 0.05 \\
0.53 \pm 0.09\end{array}$ & $\begin{array}{l}0.65 \pm 0.07^{\mathrm{a}} \\
0.61 \pm 0.08^{\mathrm{a}}\end{array}$ & $\begin{array}{c}8.12 \pm 7.17^{\vee} \\
16.93 \pm 12.20\end{array}$ \\
\hline
\end{tabular}

a: All restorative materials showed increased surface roughness values after bleaching procedures ( $p<0.05$ ).

${ }^{*}$ : Differences in percentage values of surface roughness of TATL and IPS 2 were lower than TEC in WHP group, $p<0.05$

*: Differences in percentage values of surface roughness of TATL bleached with LW were significantly higher than bleached with WHP,$p<0.05$

All restorative materials showed an increased surface roughness value after bleaching procedures $(p<0.05)$. Univariant analysis revealed that there were significant differences among the changes of surface roughness values for the tested materials $(\mathrm{F}=4.97, \mathrm{p}<0.05)$ and among bleaching methods $(\mathrm{F}=11.37, \mathrm{p}<0.05)$. In WHP group, the surface roughness values of the TEC were higher levels than TATL and IPS2 (ANOVA, $\mathrm{p}<0.05$ ). There were no statistically significant differences in changes of the surface roughness among tested materials for LW group. Independent $t$ test demonstrated that the differences in percentage values of the surface roughness of TATL bleached with LW were higher levels than bleached with WHP $(\mathrm{p}<0.05)$. On the other hand, the changes of the surface roughness of the other 
restorative materials bleached with $\mathrm{LW}$ were similar levels in WHP applications ( $\mathrm{p}>0.05)$.

Figs 1, 2, 3 presents scanning electron microscope images of the bleached restorative materials surface. Different specimens from groups bleached with LW and WHP had different topographies.

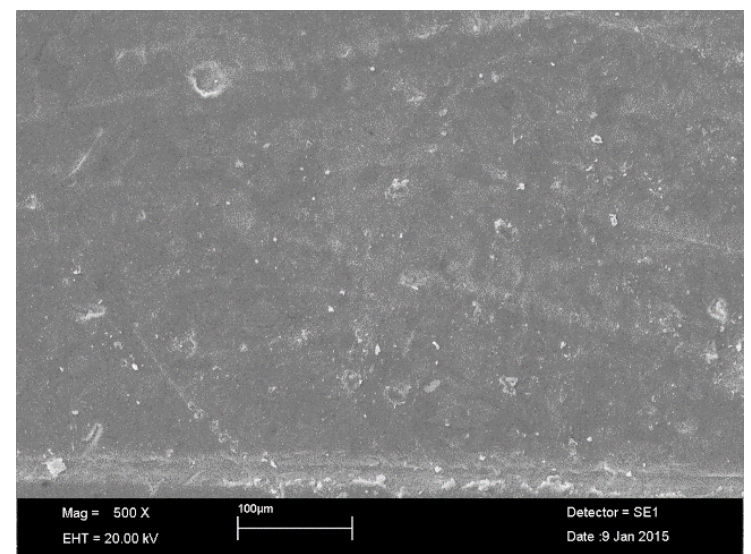

Figure 1: Representative SEM micrograph of TEC specimen bleached with WHP with the highest mean surface roughness value.

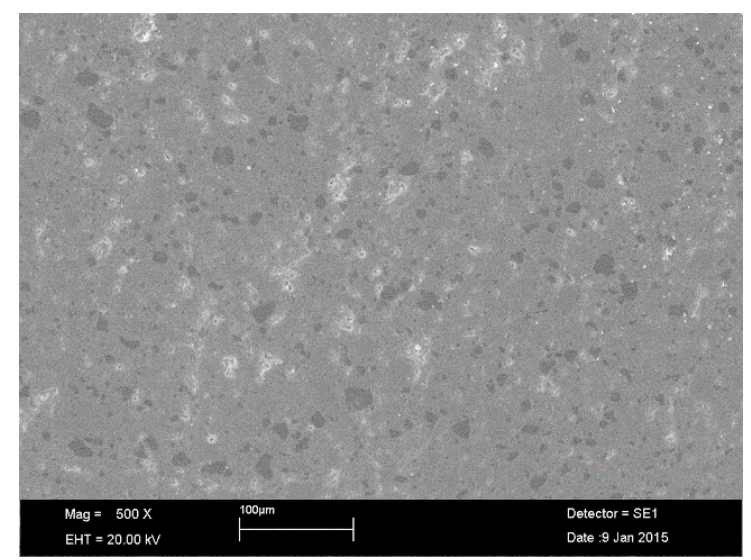

Figure 2: Representative SEM micrograph of TATL Hard specimen bleached with LW with the highest mean surface roughness value.

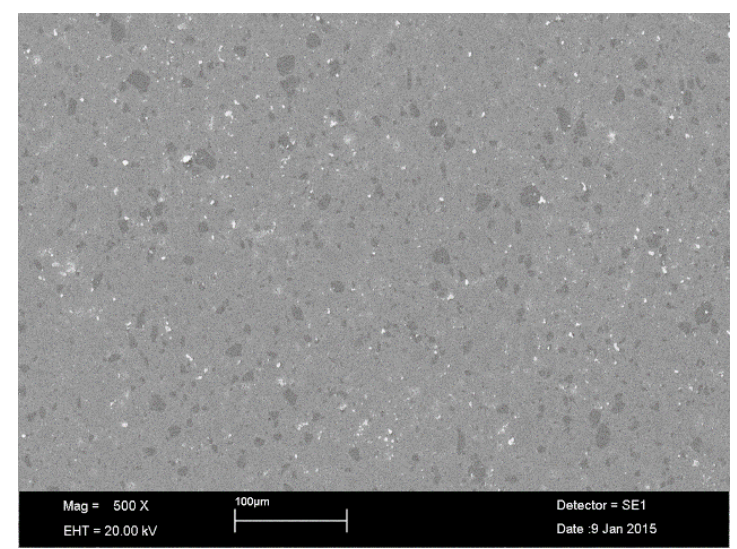

Figure 3: Representative SEM micrograph of TATL specimen bleached with WHP with the highest mean surface roughness value.

\section{DISCUSSION}

In this vitro study surface roughness values of restorative materials tested changed after exposed with two bleaching systems so the null hypothesis that the two in-office bleaching techniques would not alter the values of surface roughness was rejected. In comparison of the two bleaching techniques, both of the bleaching techniques demonstrated similar effects on surface roughness of restorative materials. After activated bleaching the surface roughness of restorative materials increased, so the second hypothesis of this study that there were no significant difference between two bleaching techniques was accepted.

With respect to the surface roughness of different esthetic materials after two bleaching system, this in vitro study showed that WHP and LW bleaching technique causes the changes in the surface of the materials tested. Some investigations have been published analyzing the efficacy of different concentrations of the carbamide peroxide or hydrogen peroxide regarding the bleaching procedures. ${ }^{19-23}$ The studies demonstrated that $35 \%$ carbamide peroxide or $35 \%$ hydrogen peroxide regarding in-office bleaching procedures were not detrimental effects on the surface roughness of the microfilled and hybrid composite resins ${ }^{19}$, compomers, giomers, resin-modified glass ionomer cements ${ }^{23}$ and ceramic restorations. ${ }^{21}$ On the other hand, Dogan et al. ${ }^{24}$ found that surface roughness of microfilled, nanohybrid and ormocer-based resin composites were decreased upon bleaching with $37 \%$ carbamide peroxide, $35 \%$ hydrogen peroxide and $16 \%$ carbamide peroxide. However, Hafez et al. ${ }^{18}$ reported that $35 \%$ or $38 \%$ hydrogen peroxide office bleaching agents significantly increased the surface roughness of the microfilled and microhybrid composites. Again Rosentritt et $a l{ }^{25}$ found that the surface roughness of the tooth colored restorative materials, hybrid composites, microfilled composite, compomer, and ormocer, increased after bleaching. The 
results of the present study are in agreement with the findings of these previous studies. ${ }^{24,25}$ In current study, nanofilled, nanohybrid, microhybrid, nanohybrid, ormocer and ceramic specimens were used for the bleaching of the restoration surface. All restorative materials were polished and $35 \%$ hydrogen peroxide, as in-office bleaching agent was applied for 10 minutes and photoactivated for $20 \mathrm{~s}$. The results of present study cannot be affirmed that tested composites, ormocer and ceramic were resistant under bleaching systems. The changes in surface roughness of different restorative materials after bleaching are material's composition and time dependent.

The use of laser energy has some advantages in-office bleaching products. Studies demonstrated that the laser-activated bleaching has no any ultra structral effects within enamel. ${ }^{26}$ Gurgan et al. ${ }^{27}$ recommended that bleaching with laser resulted less tooth and gingival sensitivity than plasma arc lamp or LED system. In present study, for the bleaching of the different composition of the restorative materials, 46\% HP was applied approximately $1 \mathrm{~mm}$ thickness on the specimen's surface for 5 min and then photoactivated with diode laser system (wavelength $980 \mathrm{~nm}$, average power 7 watt, energy setting $200 \mathrm{~J}$, continuous mode) for 30 s. Diode laser activated $46 \%$ hydrogen peroxide caused an increasing in surface roughness of nanofilled, nanohybrid, microfilled, microhybrid, ormocer and ceramic materials.

In this study, as Univariant analysis revealed that both light activated bleaching techniques significantly increased the surface roughness of restorative materials. One reason for this is that there might be an increase in release of free radicals from bleaching agents when the temperature rises, thus inducing greater effects on dental materials. ${ }^{28}$ Also a previous study ${ }^{29}$ presented that surface roughness of a ceramic material increased with increasing HP concentration. In this study the bleaching agents used are at high concentrations
(35\% and $46 \%$ ). Another result of this study was that two bleaching procedures were not significantly different in the changing of the surface roughness of the restorative materials, except the TATL. For ormocer (TATL) material, LW causes higher the degradation of the surface properties than WHP technique. Ormocer-based composite resins consisted of organic polymers, inorganic unit and inorganicorganic unit (polysiloxanes). ${ }^{30}$ Dogan et al. ${ }^{24}$ suggested that bleaching agents might cause degradation in the organic polymers of ormocers.

It has been found that surface roughness of the microfilled composite resins (Durafil) was the lowest values compared with themicrohybrid (GradiaDiect) and an Ormocerbased (Admira) resin composite upon HP bleaching. ${ }^{24}$ On the contrary, microhybrid composites (TPH3) showed higher surface roughness than microfilled resins (Durafil) bleaching with $35 \%$ hydrogen peroxide and $38 \%$ hydrogen peroxide. In present study, for nanohybrid composite (TEC), a significant increase in surface roughness was observed in WHP group and these changes were higher levels than ormocer (TATL) and ceramic (IPS2). The lower changes of the surface roughness of the ceramics might be depend on the brittle, hard, strong in compression properties. This study also showed that the changes of the surface roughness among tested materials were similar levels in LW group.

When evaluating the change on surface roughness values, it is important to indicate that the specimens were stored in distilled water instead of saliva. Further in vivo research is needed to determine the surface roughness of restorative materials after bleaching treatment. The effects of office bleaching agents should be known and applied cautiously when a colored restoration is bleached or a restoration is neighbouredwith the tooth bleached. 


\section{CONCLUSIONS}

It has been concluded that there was a significant surface roughness in all restorative materials after office bleaching procedures with blue light-emitted diode (LED) and diode laser (DL) photoactivation. After WHP bleaching technique, the surfaces of the nanohybrid TEC material showed significantly higher roughness values than ormocer (TATL) and ceramic (IPS2). However, surface roughness in all tested materials for LW bleaching was minimal, when measured with surface roughness tester. The evidence from this study, would suggest that bleaching may adversely affected the surface texture of the restorative materials, therefore patients who have restorative materials should be informed of its possible effects.

\section{ACKNOWLEDGMENTS}

The authors do not have any financial interest in the companies whose materials are included in this article.

\section{REFERENCES}

1. Haywood VB. Achieving, maintaining and recovering successful tooth bleaching. J Esthet Dent 1996; 8:31-38

2. Haywood WB, Berry TG. Natural tooth bleaching Chapt15 Fundamentals of Operative Dentistry: A Contemporary Approach $2^{\text {nd }}$ Chicago Quintessence Publishing; 2001

3. Matis BA, Mousa HN, Cochran MA, Eckert GJ. Clinical evaluation of bleaching agents of different concentrations. Quintessence Int 2000;31:303-310

4. Sulieman M. An overview of bleaching techniques, 1: history, chemistry, safety and legal aspects. Dent Update 2004;31:608-616

5. Sulieman M. An overview of bleaching techniques: 2. Night guard vital bleaching and non-vital bleaching. SADJ 2006; 61:352-354

6. Joiner A. The bleaching of teeth: a review of the literature. J Dent 2006;34:412-419

7. Luca G, Fabio B, Claudia B, Michele N, Daniele SR. A randomized clinical trial comparing at-home and in-office tooth whitening techniques. J Am Dent Assoc 2010;141:1357-1364

8. Dadoun MP, Bartlett DW. Safety issues when using carbamide peroxide to bleach vital teeth-a review of the literature. Eur J Prosthodont Restor Dent 2003;11:9-13

9. Buchalla W, Attin T. External bleaching therapy with activation by heat, light or laser-a systematic review. Dent Mater 2007;23:586596

10. Domínguez A, García JA, Costela A, Gómez $\underline{\mathrm{C}}$. Influence of the light source and bleaching gel on the efficacy of the tooth whitening process Photomed and Laser Surg 2011;29:5359

11.Luk K, Tam L, Hubert M. Effect of light energy on peroxide tooth bleaching. J Am Dent Assoc 2004;135:194-201

12. Walsh LJ. The current status of laser applications in dentistry. Aust Dent J 2003; 48:146-155

13.Sun, G. The role of lasers in cosmetic dentistry. Dent Clin North Am 2000;44:831850

14.Zhang C, Wang X, Kinoshita JI, Zhao B, Toko T, Kimura $\mathrm{Y}$ et al. Effects of KTP laser irradiation, diode laser and LED on tooth bleaching: A comparative study Photomed Laser Surg 2007;25:91-95

15. Turker SB, Biskin T. Effect of three bleaching agents on the surface properties of three different esthetic restorative materials. J Prosthet Dent 2003;89: 466-473

16. Moraes RR, Marimon JLM, Schneider LFJ, Sobrinho LC, Camacho GB, Bueno M. Carbamide peroxide bleaching agents: effects on surface roughness of enamel, composite and porcelain. Clin Oral Investig 2006;10:23-28 17. Atali PY, Topbasi FB. The effect of different bleaching methods on the surface roughness and hardness of resin composites. J Dent Oral Hygiene 2011;3:10-17

18.Hafez R, Ahmed D, Yousry M, El-Badrawy W, El-Mowafy O. Effect of in-office bleaching on color and surface roughness of composite restoratives. Eur J Dent 2010;4:118-127 
19. Sharafeddin F, Jamalipour G. Effects of 35\% carbamide peroxide gel on surface roughness and hardness of composite resins. J Dent (Tehran)2010;7: 6-12

20.Pruthi G, Jain V, Kandpal HC, Mathur VP, Shah N. Effect of bleaching on color change and surface topography of composite restorations. Int J Dent 2010; 2010:695748. doi: 10.1155/2010/695748. Epub 2010 Dec 22

21.Zaki AA, Fahmy NZ. The effect of a bleaching system on properties related to different ceramic surface textures. J Prosthodont 2009;18:223-229

22.de A Silva MF, Davies RM, Stewart B, DeVizio W, Tonholo J, da Silva Júnior JG et al. Effect of whitening gels on the surface roughness of restorative materials in situ. Dent Mater 2006;22:919-924

23. Wattanapayungkul P, Yap AU. Effects of inofficebleaching products on surface finish oftooth-colored restorations. Oper Dent 2003;28:15-19

24.Dogan A, Ozcelik S, Dogan OM, Hubbezoglu I, Cakmak M, Bolayir G. Effects of bleaching on roughness of dental composite resins. J Adhes 2008;84: 897-917

25.Rosentritt M, Lang R, Plein T, Behr M, Handel G. Discoloration of restorative materials after bleaching application. Quintessence Inter 2005; 36:33-39

26. Goharkhay K, Schoop U, Wernisch J, Hartl S, De Moor RT, Moritz A. Frequency doubled neodymium:yttrium-aluminum-garnet and diode laser-activated power bleaching--pH, environmental scanning electron microscopy, and colorimetric in vitro evaluations. Lasers Med Sci 2009;24:339-346

27.Gurgan S, Cakir FY, Yazici E. Different light-activated in-office bleaching systems: a clinical evaluation. Lasers Med Sci 2010;25:817-822

28. Yu H, Li Q, Cheng H, Wang Y. The effects of temperature and bleaching gels on the properties of tooth-colored restorative materials. J Prosthet Dent 2011;105:100-107

29. Abu-Eittah MR, Mandour MH. In vitro study of the effect of three hydrogen peroxide concentrations on the corrosion behavior and surface topography of alumina-reinforced dental ceramic. J Prosthodont 2011; 20:541-552 30.Hickel R, Dasch W, Janda R, Tyas M, Anusavice K. New direct restorative materials. Inter Dent J 1998;48:3-16

\section{Correspondence Author}

Özgün Yusuf ÖZYILMAZ

Istanbul Medipol University

Faculty of Dentistry,

Department of Prosthodontics,

Istanbul, Turkey

Phone: +902124607651

Fax: +902124607070

E-Mail: oyozyilmaz@medipol.edu.tr 